\title{
The perception of gastronomic events within the framework of sustainable tourism development
}

\author{
N. Pavia ${ }^{1}$, J. Gržinić ${ }^{2} \&$ T. Floričić ${ }^{2}$ \\ ${ }^{1}$ Faculty of Tourism and Hospitality Management, \\ University of Rijeka, Croatia \\ ${ }^{2}$ Faculty of Economics and Tourism, \\ Juraj Dobrila University of Pula, Croatia
}

\begin{abstract}
Recognising modern tourist demands, tourist destinations perceive comparative advantages and potential available resources, placing them in the tourist market through selective tourist products and events. "How are gastronomic events perceived within the framework of sustainable tourist development?" is the research problem area, which leads to the definition of the paper's purpose and goal. It relates to the assessment of perception of the importance of organisation of gastronomic events within the framework of sustainable tourist destination development by the local producers of original tourist products and the local population.

The research includes an assessment of how many gastronomic events intensify gastronomic tourism and how they valorise the pre and post tourist season, which the Strategy of Development of Croatian and Istrian Tourism recognises as the terms which must be touristically intensified, strategically enriching the tourist offer. In the paper, the social component of sustainability is also perceived through the attitudes of gastronomic event visitors.

The research, which affirmed new scientific knowledge, was conducted by means of survey and interview methodology. For data processing, quantitative methods of analysis, synthesis, comparison, meta-analysis and other scientific and research methods were used. The generated knowledge confirms the purpose of the paper, which is channelled towards the determination of the importance of promotion of original products at gastronomic events, in accordance with the
\end{abstract}


principles of sustainability. The research was conducted at the event Days of Fresh Olive Oil in Vodnjan, which was organised as a sustainable gastronomic tourist event.

Keywords: tourist event, social sustainability, gastronomic tourism, destination offer.

\section{Introduction}

The cultural landscape represents a spatial and natural correlation of the environment and human activity. Recognising the values of the cultural landscape as the world cultural heritage represents the recognition and preservation of a specific spatial "memory" of a particular way of living and an important part of social identity and quality of life of a community, which is in line with the concept of sustainable development.

The Master Plan of tourism development of Istria as a strategic document of future development stresses the importance of preservation of natural and cultural resources as a fundamental comparative advantage and a key element of the "brand" of Istria as a tourist destination. The Plan envisages improvement of the sector according to the natural (by 30\%) and socio-cultural (by 40\%) criteria, with the aim to achieve the vision of creation of the "tourist brand" of Istria as a "Green refuge of the Mediterranean" [1].

The Master Plan of tourism development of Istria attempts to provide diversity of offers for different guests, extend the season to nine months, raise the local population's quality of life, preserve the local culture, save the clean environment, open possibilities for a higher guest expenditure and develop high quality tourism, oriented towards the selective forms of offer (gastronomic tourism).

Given the recent uncontrolled development of mass tourism in the area of the Croatian Adriatic, thus equally in Istria, the total tourist destination offer is generally unrecognisable; unified segments in the sense of commercial offer (souvenirs), entertainment (music, dance, sports) and gastronomy (international cuisine) dominate. The same is related to the weakening of the cultural identity of the environment where guests come, uncritical acceptance of foreign values and models and misunderstandings between the local population and visitors.

The conducted research will examine how successful the model of valorisation of gastronomic resources and cultural heritage through traditional meals and provisions is.

\section{Methodology}

As an autochthonous provision, olive oil is the foundation of traditional gastronomy. It can be valorised through tourism by means of organised events, thus contributing to the development of sustainable cultural tourism.

For the purposes of testing of the hypothesis, three researches were conducted, the results of which synergically contribute to the derivation of conclusions. The first research is pertinent to examination of attitudes of the 
exhibitors - producers of olive oil at the event, followed by the research into the attitudes of event visitors and, finally, an interview was conducted with the President of the Hostelry Guild, which implements traditional gastronomy and provisions in tourist expenditure through the restaurant business. In the paper preparation, methods of data collection and creative thinking techniques, as well as other scientific and research methods were used. The statistical method includes processing and illustration of statistical information while meta-analysis and the historical method were used in the analysis of numerous scientific and professional works, with the aim of importance evaluation of sustainable tourism offer and events that support their marketing.

Research methods also include interviews, focus groups and questionnaires. Event exhibitors and tourists were asked to define the current state of development and to predict future potentials. Authors' arguments and predictions are also presented in the paper. Sustainable events that promote sustainable products are impetus for a qualitative response to globalisation processes (synergy of localisation, globalisation and sustainable development). Methodology is oriented to the research of the concept of sociological sustainability and the eco-oriented business philosophy on the repositioning of Istria tourist destination.

\section{Conceptualisation of the social aspect of sustainable development and tourist valorisation of events: theory and literature review}

There are relatively very few event researches in Croatia. Among the most important researches, chapters should be identified in books which, among others, clarify the phenomenon and significance of events in the improvement of tourist offer of receptive regions (Blažević [2], Pančić-Kombol [3]). In addition to these publications, also important are papers on the significance of particular sports events for tourism (Zekić [4], Skoko and Vukasović [5], Pranić et al. [6]), festivals in the Croatian part of the Adriatic coast (Škrbić Alempijević et al. [7]), as well as the influence and significance of urban festivals (Piškor [8], Kikaš et al. [9]).

Event tourism is the term used for all forms of tourist traffic motivated by the staging of various events (Vukonić and Čavlek [10]) and it includes visits to all planned events which have a tourist purpose and form a part of the attraction basis of a specific destination. There are eight main types of events: cultural, political, economic, entertainment, scientific and educational, sports competitions, recreational and private events. Getz [11] describes that cultural events include festivals, carnivals, commemorations and entertainment events include concerts and award presentations and economic events, trade fairs and markets, business gatherings and sale exhibitions. Festivals are the most frequent events according to Presbury and Edwards [12]. They can have different forms from cultural to gastronomy (wine, olive oil) and attendance may vary within the range of between around one hundred and several thousand visitors (Gelder and 
Robinson [13]). Events are associated with the development of the special interest tourism and represent strength in the SWOT analysis of the tourism development of Istria (Stipanović et al. [14]).

The definitions of sustainable development as a concept which emerged at the turn of the 20th century are numerous and, in general terms, it can be defined according to WCED (1987) as "the development that meets the needs of the present without compromising the ability of future generations to meet their own needs" [15]. From each individual, the sustainable development policy requires sufficient responsibility to recognise what could be done and achieved once that individual recognises that his own interests are inseparably connected with the interests of the community, argue Pavić and Rogošić [16].

Sustainable development includes the change in the structure of global production and expenditure, while not disturbing eco systems. Črnjar [17] explains that it establishes a positive relationship between tourism development and the protection of the environment. It is the capacity of the environmental sustainability which determines the permitted scope of development, avoiding occurrence of unacceptable ecological and social impacts, by which it becomes a significant ecological and economic norm of natural resource management.

The sustainable tourism development was created as a counter-balance to mass, consumer and unsustainable tourism, whose goal is profit and that to the detriment of the local community environment and tradition. Modern trends of development of tourism of Istria, as a leading Croatian tourist region, rely on new technologies that provide lucrative marketing and on the concept of sustainable tourism and social responsibility (Grzinic and Floricic [18]). They include resource management in the manner that basic economic, social and aesthetical requirements are satisfied, at the same time preserving the cultural integrity, fundamental ecological processes and biodiversity defines Berger [19]. Klarić [20] explains that sustainable tourism development uses natural and cultural heritage to increase the number of visitors and profits, but in a way that it is saved also for future generations.

Socio-cultural sustainability represents a concept in which the population is the main factor of the geospatial system. It is characterised by the following existential functions: dwelling and life in the community, work, supply, education and use of free time. Crnjar [17] believes that education is becoming a global educational industry and science, prerequisite and starter of sustainable development. Developing tourism in tourist destinations impacts increase of local awareness about the financial value of natural and cultural resources. Developing it in sustainable way stimulates the feeling of pride for local and traditional heritage, as well as the interest in its preservation.

Considering the components of social sustainability, Klarić [20] lists: changes in the structure of population, migration movements, labour problems, change of cultural identity and quality of tourist experience. In tourist areas, the local population is employed in the tourism industry and other associated service businesses. Through the employment function, social development is initiated by means of creation of work posts, reallocation of income and removal of poverty and the destination management is incorporated in various destination 
subsystems in the sense of linking of economic subjects and tourist offer (Magas [21]). Within the framework of sociological sustainability, cultural sustainability is developed, which includes the method of cultural heritage utilisation and management. In defining cultural and historical heritage, according to UNESCO, Jelinčić [22] lists: monuments, groups of buildings and localities of historical, aesthetic, archaeological, scientific, ethnological or anthropological value. The main goals of cultural tourism include: prevention and preservation of local cultural heritage, encouragement of quality and diversity of cultural products, promotion of integrative culture and tourism policy, capitalisation of local particularities and advantages and assurance of quality of life and respect of local population's cultural identity. Synergical partnership among tourism and all professions dealing in protection and preservation of material and non-material cultural heritage is important for the sustainable development of cultural tourism. This also includes valorisation of folklore performances, autochthonous gastronomy, revitalisation and renewal of traditional crafts and traditional construction, as well as the overall cultural heritage.

Tourists have direct contact with unique social, historical and heritage characteristics of the destination they visit, as well as with its local lifestyle, which assists them with their perception of the present with a more complex understanding.

Sustainable tourism must be harmonised with the local community, i.e. the population of the locality in which tourist activity takes place (Swarbrooke [23], Weaver [24]) as well as sustainable management of festivals, congresses and events (Presbury and Edwards [12], Musgrave [25]).

Gastronomic diversity of particular tourist destinations and climates is subject to geographical and climatic conditions, historical circumstances and specific, radically different, customs and traditions of the people who live in particular areas. Križman Pavlović [26] quotes gastronomy as one of the variables which determine the tourist destination image as the fundamental receptive tourist unit.

The basis of Istrian gastronomy within the framework of the Mediterranean gastronomy is extremely healthy, natural ingredients, coming from ecological zones which are preserved and spared from excessive industrialisation and chemical treatments. Gastronomic elements, i.e. dishes and drink which are identified with the Istrian peninsula are based on fruit and ingredients from the sea and vegetable cultures characteristic for the Mediterranean climate, with strong presence of aromatic herbs and wild growing plants, such as asparagus or truffles. As Istria abounds both in autochthonous produce and characteristic specialities, the potential for their valorisation through thematic gastronomic events has been recognised. Some of them are: International Prosciutto Fair, Days of Istrian Asparagus, Mushroom Days and Istrian Truffle Days/Weekend, With Sausage to Europe, Oleum Olivarum and New Olive Oil Days. Illustration of tourist overnights, realised in the pre and post season periods follows, as well as the implication of importance of their intensification aimed at a more successful tourism development.

As autochthonous provisions form a base for the preparation of traditional folk dishes, they are also valorised through events, as a segment of non-material 
cultural heritage of the Istrian area: Festival of Istrian Manestra in Gračišće, Valbandon 'spod čripnje (dishes prepared under a baking lid "čripnja"), Polenta Festival and others. Events are usually held in the periods of tourist pre and post season and are the starters of rural tourism of municipalities in the sense of development of agrotourism households, traditional restaurants and taverns, as well as other selective forms of sustainable tourism.

Table 1: Tourist overnights in Istria in pre and post season in the years 2007, 2008 and 2009.

\begin{tabular}{|l|c|c|c|c|c|}
\hline & \multicolumn{3}{|c|}{ Years } & \multicolumn{2}{c|}{ Index } \\
\hline Month & 2007 & 2008 & 2009 & $2007 / 09$ & $2008 / 09$ \\
\hline March-April & 601,439 & 405,893 & 492,802 & 122.0 & 83.0 \\
\hline May & $1,098,884$ & $1,305,625$ & $1,105,969$ & 99.4 & 118.1 \\
\hline September & $2,049,774$ & $2,001,787$ & $2,092,101$ & 97.9 & 96.0 \\
\hline October & 310,254 & 352,844 & 331,991 & 94.0 & 106.3 \\
\hline Total & $4,060,351$ & $4,076,149$ & $4,022,863$ & 101.0 & 101.3 \\
\hline Overnights - Istria & $17.63 \mathrm{mil}$ & $17.96 \mathrm{mil}$ & $18.13 \mathrm{mil}$ & - & - \\
\hline $\begin{array}{c}\text { Share in overnights in } \\
\text { Istria }\end{array}$ & $23.05 \%$ & $22.69 \%$ & 22.19 & - & - \\
\hline
\end{tabular}

Source: Authors' processing according to: Tourism of Istria in figures, County of Istria Administrative Section of Tourism, Poreč, September 2010, original data of the State Institute of Statistics, communications, [27].

While reviewing the out of season periods, considerable oscillations can be noticed in the pre-season periods of one year as opposed to another. This is the result of a changeable calendar of religious holidays in Western Europe. When considering the total number of indicators, it is evident that pre-season and post-season months of previous years were slightly better, which points to the need for improvement of offers by means of creative tourism projects and events. In these projects, the solution can be seen for an increase in the shares of the off-season months, as well as the total tourist season overnights.

\section{Findings and discussion}

Olive cultivation and production of olive oil in Istria marks a three thousand year-old tradition and boasts numerous monuments and artifacts from the Roman period. The remains of olive oil processing plants from the area of the National Park Brijuni and from Barbariga record evidence that olive oil was once produced for Roman emperors [28].

Today, Croatian olive cultivation includes 30,000 hectares of olive groves, of which 98 percent is privately owned and where 5 million olive trees are cultivated from a total of 60 acclimatised sorts. The annual olive crop of 
38,000 tonnes of olives is processed in 180 specialised olive oil processing plants, yielding 51 hectolitres of oil [29]. Istria has 5,000 hectares of olive groves with 1,050,000 olive trees and listing in the Flos Olei Guide of best olive oils in the world speaks of the exceptional quality of the product [30]. The basic quality parameters of extra virgin olive oil, as the best, refer to the totality of properties and functions which can satisfy consumers' needs. They are free fatty acids, sensor grade and so-called peroxide number, K-numbers. The republic of Croatia adopted European Union regulations pursuant to the standards of the quality of olive oil and table olives; categories and market quality standards, as well as physical and chemical and sensory properties, are defined.

Olive cultivation and olive oil are promoted as an autochthonous business activity and a trade mark and olive harvest and oil production is increasingly becoming an attractive tourist product. Modern guests look for nature and want to be in touch with it, avoiding excessively built-up destinations of mass tourism, seeking exclusivity of experience which selective forms of tourism provide. Croatia aims to be perceived as a country of healthy, Mediterranean cuisine. In the aspiration to broaden knowledge about the gastronomic significance and healing properties of olives and olive oil, as well as to encourage gastronomic creations based on autochthonous resources, it is important to continuously advance experience about the gastronomic usability of olives. Ecologically produced olive oil, together with other ecologically produced autochthonous food, is being included in Croatian tourist offer and represents the potential for its comparative advantage. In this way, contributions are made to scientific and professional knowledge and to a higher quality and imaginative gastronomic offer of hostelry facilities.

Fresh Olive Oil Days is an event which takes place in mid-November in Vodnjan, lasting three days. In 2013, the 9th event was held, organised by the Town of Vodnjan, some eighty exhibitors, mostly from Istria, were presented with over two hundred olive oils and wine, brandy, honey, beer, truffles and numerous other autochthonous products. This represents growth in comparison with the last year and indicates that Fresh Olive Oil Days are becoming an important event for promotion of olive oil value in the region. Several thousand people visited the event and, on top of educational tasting sessions, took part in the gastro exhibition, competition, review, workshops and panel sections related to the offer of olive oil and other autochthonous Istrian products. At the event, also some innovative gastronomic products, based on olives, were presented: olive jam, chocolate with olives, desserts with olive oil, which have the potential to develop and be affirmed through sustainable development of tourism.

Within the event, a free educational tour by the tourist train 'Art and Oil Tour' also took place. It included visits to the mushroom exhibition, exhibition of four Vodnjan artists under the title 4in1 at the Town Palace and olive oil tasting at the San Lorenzo olive oil processing plant.

It was estimated through the media that the event contributes to the promotion of the values of olive oil and its use in everyday life and that, at the same time, it extends the tourist season, both in Istria and Croatia. The perception of sociological and economic sustainability as an impalpable value contributes to 
tourism development and attracts knowledgeable consumers to the destinations of sustainable and socially responsible tourism.

The study was conducted on the sample of 27 exhibitors at the event New Olive Oil Days, which was held in Southern Istria, in the Town of Vodnjan, positioned as the centre of Istrian olive cultivation. Out of the total sample, 19 exhibitors $(70 \%)$ were entrepreneurs, olive oil producers, while 8 exhibitors $(30 \%)$ presented gastronomic products related to olive oil and utensils made of olive tree wood as an autochthonous raw material. Development of olive cultivation is the interest sphere for all, as well as its valorisation through sustainable tourism.

As producers of olive oil, the exhibitors are placed into three categories: small, medium and large and the data in the sample points to the fact that, regardless of the company size, they valorise the promotion and placement of that autochthonous product through tourism.

Table 2: $\quad$ Participation of olive oil producers at the event according to total production.

\begin{tabular}{|l|l|l|}
\hline Annual production & Number $=\mathrm{N}$ & $\%$ \\
\hline Small producers - up to 1,000 litres of oil & 10 & 52.6 \\
Medium-size producers - up to 2,000 litres of oil & 4 & 21.0 \\
Large producers - over 2,000 litres of oil & 5 & 26.3 \\
\hline Total & 19 & 100.0 \\
\hline
\end{tabular}

The research of the frequency of participation in gastronomic events shows that $7.4 \%$ of exhibitors took part in the event for the first time, $3.7 \%$ of exhibitors took part occasionally, while $88.8 \%$ of producers take part in the event every year.

To the question on production of varietal oils, as differentiation of quality and exclusiveness of specific sorts of olives, $63 \%$ of exhibitors confirmed the production of different sorted oils, while $37 \%$ of producers do not manufacture varietal oils, which is possibly conditioned by small production or by on-recognisability of the importance of product differentiation itself.

Table 3: Assessment of the influence of event organisation on gastronomic tourism sustainable development.

\begin{tabular}{|l|l|l|l|l|l|}
\hline Question & YES & & NO & & TOTAL \\
\hline & $\mathrm{N}$ & $\%$ & $\mathrm{~N}$ & $\%$ & $\%$ \\
\hline $\begin{array}{l}\text { Do you think that the event encourages } \\
\text { gastronomic tourism? }\end{array}$ & 27 & 100 & 0 & 0 & 100 \\
\hline $\begin{array}{l}\text { Do you think that olive oils are well } \\
\text { presented through tourist offer? }\end{array}$ & 21 & 78 & 6 & 22 & 100 \\
\hline $\begin{array}{l}\text { Would you be prepared to invest in } \\
\text { tourist marketing of olive oil? }\end{array}$ & 25 & 93 & 2 & 7 & 100 \\
\hline
\end{tabular}


In assessment of market recognisability of varietal olive oils as gastronomic brands, $70.4 \%$ of exhibitors believe that only certain consumers recognise and choose varietal oils, $22.32 \%$ of them believe that varietal oils are a recognisable gastronomic brand, while $7.4 \%$ of exhibitors believe that varietal oils are not recognisable. In consideration of the potential of valorisation of varietal oils as a gastronomic brand which contributes to sustainable tourism development, $26 \%$ of respondents recognise the possibility of development and $74 \%$ believe that the potential for this is great.

The analysis of the obtained results records that all exhibitors at the event believe that it stimulates the development of gastronomic tourism. To the question whether they believe that olive oils are well presented through tourist offer, $78 \%$ of them assess their tourist promotion as successful and $93 \%$ of respondents express their preparedness to further invest in tourist marketing of olive oil.

Aiming at getting a complex and comprehensive picture and assessment of the importance of gastronomic event organisation within the framework of sustainable development of destination tourism, attitudes of the event New Olive Oil Days in Vodnjan have also been examined. Using the random sample method, 60 visitors, of which $20 \%$ were tourists and $80 \%$ were local folk were asked the relevant questions. This points to the facts that the frequency of tourists in the post-season period (November) is low and that there is room for a stronger tourist promotion in the emissive markets. This data also points to the fact that the local population considers olive oil, as an autochthonous product, to be interesting, recognising the potential for its tourist valorisation and, at the same time, speaks of the awareness of the local population about their own values which need to be valorised, preserved and further sustainably developed.

The results of the research in the frequency of visits to gastronomic events show that $13.3 \%$ of respondents were visiting the event for the first time, $70 \%$ of them visit occasionally, while $16.7 \%$ visit the event every year. To the question about the recognition of varietal oils, $60 \%$ of respondents answered affirmatively to the question and, by further research into their opinion about the recognition of oils as a gastronomic brand in the market, $36.6 \%$ of them believe that oils are not recognisable, $53.4 \%$ of the respondents occasionally choose and use varietal oils, while $10 \%$ recognise and specifically choose exact sorts of olive oil. This points to the fact that there is room for education of both tourists and local population within the framework of sociological sustainability. To the question about the influence of this gastronomic event on sustainable tourism of Istria, $96.7 \%$ of respondents believe that the event stimulates its development. In consideration of the current and future potential for the development of olive oil as a segment of sustainable tourist offer, $93.3 \%$ of respondents believe that olive oils are well presented through tourist offer, but that there is still further potential for the development of olive oil as a tourist brand. The share of $76.7 \%$ of respondents recognise certain opportunities for development, while $20 \%$ of respondents believe that the possibility for development is great, which represents the basis of future marketing activity and work in tourist markets with 
the aim to intensify sustainable valorisation and placement of the autochthonous product through tourism.

The third part of the research into the importance of organisation of gastronomic events for the purposes of sustainable tourist valorisation was conducted with the President of the Croatian Restaurant Guild [31], as an umbrella organisation which promotes autochthonous gastronomic offer in hostelry facilities, recording the economic impacts of its placement in tourism. The following attitudes and opinions were expressed:

- Istrian gastronomic specialities have been neglected and are not well presented in foreign markets; there is room for numerous marketing activities, events and different types of education.

- The rank of the quality level of Istrian gastronomic specialities is the following: (1) Olive oil, (2) Malvazija - Istrian white wine, (3) Prosciutto, (4) Cheese, (5) Truffles, (6) Manestra soup, (7) Homemade pasta (gnocchi/fusi). Poorer promotional activities and non-recognisability of the Istrian dishes are also conditioned by the organisation of restaurants in Istria, undermining of dishes and their classification into the offer of taverns and inns. This points to the need for education of hostelry workers themselves on the potentials.

- In principle, guests do not know and do not recognise traditional dishes in advance, although they accept the offer with quality presentation. They are also interested in tasting innovative dishes, as a fusion of traditional dishes and modern gastronomy.

- Although they recognise the quality of autochthonous provisions, they are not prepared to pay a slightly higher price for quality. This also refers to the choice of home-produced prosciutto or cheese from Istria, or the choice of a special, cold pressed extra virgin olive oil. The tolerance of the difference of price is a maximum of $10 \%$.

- According to the perception of tourists, the Istrian cuisine and traditional provisions are seen as being of a high quality, ecologically acceptable and "healthy" (natural methods of cultivation, chemicals free).

- Istrian restaurants are not ready or educated to better evaluate autochthonous provisions in the tourist gastronomic offer. This is due to the non-existence of a common strategy for the restaurant business and systematic education of hostelry workers and DMC companies.

- The potential for branding and profiling of tourist destinations by means of sustainable projects (events), based on gastronomic offer, has been evident. Some examples are Vodnjan - Olive oil, Umag - "švoje" (sole fish) and tomato, Novigrad - mussels. The possibility of affecting the change of tourist destination image by implementation of innovative sustainable projects based on gastronomy by means of intensive marketing in both domestic and emissive markets, education of local population and tourists, as well as by the initiative of public and private partnerships, has been recognised. 
- By the new innovative offer, organised on the principles of sustainability, new segments of consumers who appreciate and affirm new values in the tourist destination are attracted.

\section{Conclusion}

The strategic direction of development sustainability in Istria is defined as declarative and implementable at all executive levels. In accordance with the current long-term Croatian Tourism Development Strategy by 2010, based on sustainable development, all County of Istria administrative departments, as well as County developmental agencies with 94 implemented projects, support sustainable development, environmental protection, rural development, encourage small and medium entrepreneurships, tourism, culture and civil society.

The Regional Operational Plan of Istria represents an action plan for achievement of sustainability of tourism in Istria and is founded upon the bases and principles of sustainable tourism, namely: emphasising of the cultural and historical authenticity of Istria, one of the leading destinations of Croatian tourism; environmental protection of the Northern Adriatic, with encouragement of development of selective forms of tourism and promotion of the economic development by means of organising tourist visits to the authenticities of Istria.

When considering sustainable developmental directions, the potential for the valorisation of autochthonous gastronomy in the system of social and economic sustainability, has been evidenced. Valorisation is used to achieve economic benefits for producers and hostelry workers as economic subjects and, sociologically speaking, autochthonous products and dishes remain preserved in their original environment and form. The developmental potential of gastronomic valorisation, researched on the example of the event New Olive Oil Days, points to the need for strategic investment in the marketing and development of entrepreneurship with the aim to intensify future placement and promotion.

\section{References}

[1] THR in association with Horwath Consulting, Master Plan of Tourism (2004-2012) Istria, Final Document, Zagreb, 2003.

[2] Blažević, I., Turizam Istre. Zagreb: SGDH, 1984.

[3] Pančić-Kombol, T., Kulturno nasljeđe $i$ turizam, Radovi Zavoda za znanstveni rad - Varaždin, No. 16-17 Listopad 2006.

[4] Zekić, J., Univerzijada '87. - drugi ilirski preporod, Časopis za suvremenu povijest, 39 (2), pp. 99-118, 2007.

[5] Skoko, B., Vukasović, I., Organiziranje međunarodnih sportskih događaja kao promotivni i ekonomski alat države. Tržište. XX, pp. 211-230, 2008. 
[6] Pranić, Lj., Petrić, L., Cetinić, L., Host population perceptions of the social impacts of sport tourism events in transition countries Evidence from Croatia, International Journal of Event and Festival Management 3(3), pp. 236-256, 2012.

[7] Škrbić Alempijević, N., Žabčić Mesarić, R., Hrvatski priobalni festivali Sredozemlja, Studia ethnologica Croatica. 22 (1), pp. 317-337, 2010.

[8] Piškor, M., Celebrate cultural diversity! Reading the discourses of world music festivals in Croatia. Narodna umjetnost, 43(1), pp. 179-201, 2006.

[9] Kikaš, M., Mucko, B., Vukobratović, J., Kelemen, P., Urbano umjetnički festivali: kulturne politike i potencijali subverzivnosti, Studia ethnologica Croatica. 23 (1), pp. 67-92, 2011.

[10] Vukonić, B., Čavlek, N. (eds). Rječnik turizma. Zagreb: Masmedia, 2001.

[11] Getz, D., Event Tourism: Definition, Evolution, and Research Tourism Management. 29(3), pp. 403-428, 2008.

[12] Presbury, R. and Edwards, D., Managing Sustainable Festivals, Meetings and Events, Understanding the Sustainable Development of Tourism Liburd J.J. and Edwards D. (eds). Goodfellow Publishers 1td., Oxford, pp. 163-187, 2010.

[13] Gelder, G. and Robinson, P., Events, Festivals and the Arts, In: Robinson P., Heotman S. and Dieke P. (eds). Research Themes for Tourism. CAB International, Wallingford, 2011.

[14] Stipanović C., Pavia N., Floričić T., Sustainable development in increasing competitiveness of hotel offer - Case study Istria County, Proc. of the $2^{\text {nd }}$ International Scientific Conference Tourism in Southern and Eastern Europe, eds. Janković S., Croatia, pp. 279-294, 2013.

[15] World Commission on Environment and Development (WCED). Our Common Future, Oxford, 1987.

[16] Pavić, Rogošić, Održivi razvoj. Odraz, 2006.

[17] Črnjar, M., Menadžment održivog razvoja. Sveučilište u Rijeci. Rijeka, 2009.

[18] Grzinic J., Floricic T., Implementation of innovations in hotel offer promotion - case study of Istria as a tourist destination, Proc. of the 8th International Forum on Knowledge Asset Dynamics, eds. Schiuma G., Pulic A., Wellington C., Zagreb, Hrvatska, pp. 704-721, 2013.

[19] Roland Berger, Strategy Consultants, Studija o konceptu održivog razvoja - Hrvatska i svijet. Zagreb, 2008.

[20] Klarić, Z., Elementi održivosti u turizmu. Institut za turizam. Zagreb, 2011.

[21] Magaš D., Destinacijski menadžment - modeli i tehnike. Sveučilište u Rijeci. Fakultet za hotelski i turistički menadžment Opatija, 2008.

[22] Jelinčić D. A., Abeceda kulturnog turizma. Zagreb, 2009.

[23] Swarbrooke, J. Sustainable Tourism Management. Wallingford: CABI publishing, 1999.

[24] Weaver, D., Sustainable tourism: Theory and practice. Oxford: Elsevier, 2006.

[25] Musgrave, J., Moving towards responsible events management. Worldwide Hospitality and Tourism Themes. 3 (3), pp. 258-274, 2011. 
[26] Križman Pavlović D., Marketing turističke destinacije. Sveučilište Jurja Dobrile u Puli, Pula, 2008.

[27] County of Istria Administrative Section of Tourism, http://www.istraistria.hr/fileadmin/dokumenti/turizam

[28] Agroclub Association, http://www.agroklub.com/vocarstvo/poticaji-zamaslinarstvo/2150/

[29] Croatia Chamber of Commerce, http://www.hgk.hr/wp-content/files_mf/maslinovoulje_web.pdf

[30] Istria Gourmet Association, http://www.istria-gourmet.com

[31] Černjul D., Personal Communication, 17 January 2014, President of the Croatian Restaurant Guild, Pula, Croatia. 